\title{
Vitimização, vergonha e silêncio
}

\author{
Ivar César Oliveira de Vasconcelos \\ Universidade Católica de Brasília, Brasília/DF - Brasil \\ Universidade Paulista , São Paulo/SP - Brasil
}

\section{Candido Alberto da Costa Gomes}

Universidade Católica de Brasília, Brasília/DF - Brasil

DE GAULEJAC, Vincent. Les sources de la honte. Paris: Desclée de Brouwer, 2008. Trad. para o espanhol: Las fuentes de la vergüenza. Siero: Editorial Sapere Aude, 2015.

Por que as violências, como o estupro, o bullying, os maus tratos (de professores e alunos) têm a tendência de não serem denunciadas por suas vítimas? No jogo de poder, porque há uma relação dessa ordem, as vítimas tendem a ocultar o que thes aconteceu por ser humilhante. Sobre elas, derrama-se a vergonha, como mancha ignominiosa, que, assim, beneficia o agressor. Não raro esse ameaça a vítima com mais violência e antecipa que ela, envergonhada, considerará que se apresentar como tal será um ônus maior, ainda mais na desesperança de justiça, em face de certos crimes.

De fato, o autor da obra resenhada, com formação em psicologia, psicanálise e sociologia clínica, lança novas luzes sobre o tema da vergonha, fazendo-o na interdisciplinaridade que merece a sua análise. As violências físicas, psicológicas e simbólicas corroem a identidade, tornam-se um nó sociopsíquico, com frequência inconsciente. Como nos campos de concentração, levanta-se a dúvida sobre quem é mau: o carrasco ou a vítima? A vergonha se enraíza, quando a vítima não reage por dentro e/ou por fora, dependendo da situação opressora. Ao ser tratada como objeto, a vítima precisa reivindicar-se como sujeito, pois assim não se fecha na lava reprimida da impotência. Como as violências reduzem as pessoas a objetos, cumpre lembrar a Pedagogia do oprimido, de Freire (2011): a pedagogia bancária e monológica trata o aluno como coisa, uma esponja que devolverá os conteúdos, ao passo que a pedagogia dialógica o considera como um sujeito, admitindo-o capaz de construir sua identidade. Se ocorre o primeiro caso, o aluno pode reagir, com violências contra educadores e colegas, com o objetivo de proteger sua identidade. 
Pode alhear-se da escola, embora com presença física, como pode abandoná-la ou reduzir-se ao fracasso, como desistente ou reprovado. Numa instituição em si violenta, palco e objeto de violências, a vergonha é o laço que aperta o nó sociopsíquico, frequentemente recoberto pela lei do silêncio, inclusive pela coerção dos grupos de colegas. Situações assim são potenciais motivadores de suicídios “inesperados e surpreendentes", pela incapacidade de percepção dos adultos.

Por isso, o livro esclarece também educadores. Seguindo o caminho indutivo, começa por uma série de estudos de caso. Martine, na pobreza, é filha de uma prostituta e de um homem violento, homicida. Tendo sido entregue a um casal cuja filha morrera, vira Monique, o nome da filha. Submissa, torna-se mentirosa e simuladora. Michel teve infância difícil, na pobreza, numa família com segredos. Para superar, a ambição foi o motor da sua carreira e também a causa de sua demissão. A ambição enfrentou a vergonha, mas não desatou o nó. Alain não viveu a pobreza. Era acarinhado como menino-rei. Certa vez, porém, ele comete um ato infantil, ousado diante da família e de um estranho. É ridicularizado e cai do seu trono. $\mathrm{Na}$ vida social, tem sentimento prévio de que as pessoas o rejeitarão, tem inveja dos que exercem papéis centrais e, quando é o centro das atenções, a angústia o domina. Bernadette é filha de pai desconhecido e sua mãe sempre viveu na miséria. Além de excluída socialmente, passa por vexames públicos. Mãe e filha lutam pela sobrevivência. Ao entrar na escola, cabe-lhe um lugar entre os cânceres, na última fileira, enquanto os mais privilegiados se sentam na primeira. Conquanto comece bem, cumpre a profecia do fracasso e acaba por se resignar, como fazem mãe e avó: "A escola é um luxo para nós", "A escola não é para nós, estamos cheios de preocupações, de duros acontecimentos quotidianos, você sente o perigo, uma acumulação de calamidades". Como aprender e fazer deveres de casa? Bernadette se responsabiliza pelo que lhe acontece, ela é nada, carrega o fardo dos estereótipos. Certo dia, lê uma fotonovela similar à sua vida, com um final feliz. Com o estalo, imagina que sua vida não é um destino fatal, nem a culpa é sua. Então, estuda e se forma por uma instituição de elite. Compreendendo a exploração, tornase ativista partidária e encontra 'família' e amigos.

Desses casos, emergem características comuns: 1) o sentimento de ilegitimidade pela recusa da existência do sujeito; 2) o fracasso dos pais, que conduz ao sentimento de abandono e leva à aceitação de estereótipos; 3) a inferioridade, que faz sentir-se diferente dos outros, interiorizando a vergonha; 4) a violência física, 
simbólica e psicológica, que induz ao sentimento de a vítima ser má; 5) a dilaceração, isto é, rompem-se as identificações ao nível do ego; 6) a degradação, a relegação social. No caso de Bernadette, além de adulterina, é filha de pai desconhecido e é pobre; 7) o silêncio da família, a sensação de que era melhor não ter nascido, gerando vergonha no sujeito, um canal para o grupo negar sua própria vergonha; 8) inibição, quando a vítima não pode reagir e a vergonha interioriza no sujeito e o destrói.

Assim, causar vergonha, inclusive pela tortura, prisão, negação de meios, como nos campos de concentração, constitui uma arma letal. Gera a vergonha e a vergonha de ter vergonha, a identidade se rasga em mil pedaços - nestes tempos de identidades sociais, culturais e sexuais cada vez mais líquidas, como explicava Bauman (2005). O poder usa a humilhação como forma de se impor, hierarquiza pessoas e Ihes cola estigmas. Então, a vergonha adere à pele.

Avançando no percurso indutivo, o autor escolhe três teóricos: Freud, Sartre e Camus, todos convergindo para a busca da autenticidade. Para o primeiro, a vergonha é um dique contentor da sexualidade, ligado ao narcisismo e ao superego. Para Sartre, a vergonha resulta do confronto do sujeito, com a consciência de viver sob o olhar do outro. Assim, desabamos no mundo. Afinal, em Camus, que cresceu numa favela de Argel, a vergonha se associa às condições econômicas que criam a humilhação e a estigmatização dos mais frágeis. Assim, conduz à revolta contra as diversas formas de dominação e à emergência do sujeito sócio-histórico: "Revoltome, logo somos". A vergonha pode ser (ou não) um aguilhão que leva o indivíduo a existir como sujeito. Como denominador comum, o autor encontra que a subjetividade, sob múltiplas formas, encontra-se no âmago da reflexão. Por isso mesmo, as narrativas de vida, antes mencionadas, são meios por excelência para compreender a vergonha.

Os socialmente excluídos encontram sérios obstáculos para responderem ao complexo desafio, ao laborioso processo, de se tornarem sujeitos e, portanto, pessoas livres. Escreve o autor: "Quem sou eu, se não sou considerado e se a minha vida nada vale?". Desse modo, situamo-nos na dobradiça entre o social e o psíquico: eis porque são insuficientes tanto uma abordagem individual quanto social, tanto só a psicanálise quanto só a sociologia clínica, requerendo a reunião de ambas. Daí que a vergonha não se instala de uma só vez no funcionamento psíquico. Como camadas de uma cebola, o processo é longo, embora não possa ser 
visto como uma rigorosa sucessão de etapas: há o estágio do espelho e do ingresso no mundo pelo narcisismo; segue-se o estágio edipiano ou o confronto entre o interdito e a ordem simbólica; o estágio das comparações e da descoberta do mundo social; e o da adolescência, quando se afirmam as escolhas sexuais e sociais.

Convém destacar como dificuldades, em tal percurso, o classismo, o racismo e a xenofobia como formas de rejeição do outro; a existência de um pai fraco ou desautorizado (ou o vazio de um); o fracasso dos pais em geral; e a adolescência, entre a perda e a afirmação identitária. $O$ adolescente se envolve no contraditório dinamismo entre o reforço narcísico e a perda de contenção. Ter vergonha de si e se sentir mal na sua própria pele são processos frequentes a superar nesse período. Saindo do suposto ninho, em que os pais eram idealizados, o adolescente busca o exterior, com frequência, tomando seus colegas como espelho. A emergência para o exterior e a sua afirmação dependem largamente da estratificação social, das sutilezas do meio e das escolhas realizadas, num período de desenvolvimento da identidade em que a vergonha se faz presente sob diversas perspectivas. Esse último prossegue com o jovem adulto, que, em grande parte do mundo, por falta de trabalho continua dependente dos pais e adia a sua adultez. Vive, então, a pósadolescência (GALLAND, 2007), o desenrolar de um drama que solapa a afirmação da identidade, além dos males socioeconômicos. A falta de lugar para o jovem significa a sua inexistência.

Esses são aspectos também abordados pela sociologia da sala de aula (GOMES, 2011). Essa miríade de conflitos não pode escapar ao professor, nem aos educadores em geral, quer na educação básica, quer na superior. Em grande parte, essa última se converteu num pátio de espera do trabalho e da corrida de diplomas para encontrar algum lugar ao sol ou, pelo menos, na fímbria da sombra. Os indivíduos e os grupos, em contínua dinâmica, precisam ser distinguidos e receber tratamento equilibrado, o que é não raro difícil. Por isso, a pedagogia do oprimido, que conta com o existencialismo como uma das suas fontes, tem tão alto poder explicativo como orientador. A violência física ou simbólica leva à vergonha, com a dúvida: quem é mal? Eu, a vítima (que mereceria a violência), ou o agressor? Numa autobiografia analisada por De Gaulejac, destaca-se a ambição como motor para superar a vergonha da vida pregressa. Com efeito, o personagem tem tanta garra e anseio de subir, custe o que custar, que se transforma de oprimido em opressor, negando sua própria humanidade e a dos subordinados. Tratado como objeto, 
reivindica-se sujeito, mas se torna opressor de novos oprimidos. Seu desprezo pelas normas é tal, que, verifica-se na imprensa, tornou-se alvo de escândalos, em conluio com políticos corruptos.

Por esse motivo, a ambição na obra em foco é denominada de contraveneno. Basicamente, distinguem-se três reações de defesa: a psíquica, de mobilização contra os afetos que submergem o eu; a dimensão subjetiva em face dos outros, para restaurar a identidade ferida; e a dimensão social de reabilitação de si e do seu meio pela contestação. Em compensação, o fechamento na concha de si mesmo e o álcool, como outras drogas, são desvios não liberadores. Ao contrário, suscitam nova vergonha, a de as pessoas serem dependentes. Liberar-se da vergonha implica em se externar, pelo desenvolvimento das suas capacidades de criação, escrita, a militância ou o humor. É desnecessário frisar a relevância da autoescrita, notadamente, nos diários de adolescentes, como o de Anne Frank. Contudo, não se trata de exterminar a vergonha: vivendo-se no meio social, ela continua importante. A caracterização durkheimiana do fato social é aqui muito útil.

E quais as causas da vergonha, retorna o autor. A pobreza e a miséria, que geram exclusão por provocar repulsa. O pobre é responsável pela sua pobreza, mais frequentemente suspeito de preguiça: podia superá-la como alguns sobem (quantos?), o que reforça a estratificação social, não a altera. O pobre a aceita e se destrói ou se revolta, nesse caso, expulsando a vergonha, como Bernadette. Ela formula sonhos a partir de uma fotonovela, abre as suas portas e se revolta. Entretanto, a compaixão é mais rara que o desprezo e a vergonha. Os próprios serviços assistenciais criam a dependência: aceite o seu lugar! Como a fome é mais forte que a vergonha, aceita-se a submissão às burocracias. A pessoa, reduzida a objeto, deixa de ser sujeito e sofre a vergonha deliberadamente prevista como forma de legitimação social e de controle. Nos casos de violência extrema, como Auschwitz e Abu-Dabi, as vítimas são intencionalmente aviltadas, desumanizadas e vivem envergonhadas, ao passo que os carrascos têm sua válvula de escape na hierarquia, como Eichmann: eu obedecia a ordens superiores (ARENDT, 1999). Ou lutei pela pátria, prestei grandes serviços. Muitos nos campos se deixavam morrer, algo como o banzo, entre nossos escravos traficados, a culminar com o suicídio (FREYRE, 2006). Para restaurar a dignidade, é preciso, pois, re/conquistar o estatuto humano. 
Assim, do plano moral (a produção de algo condenável pelas normas sociais) ao plano psicológico (algo não acatado profundamente pelo sujeito), a vergonha põe a nu o sentimento existencial do ser que a experimenta, revelando a intimidade de cada um, a identidade tão pretendida. Daí que o olhar direto, devassador da intimidade, pode ser interpretado como ofensa. Quantas brigas em nossas escolas começam porque alguém olha diretamente para o outro? Esse é um meio de recusar a relação e a própria existência do outro como semelhante. Por isso, a exigência de baixar os olhos, forma de obedecer ao poder do outro. Com a identidade exposta, permanecem a descoberto o corpo, a mente e a alma, inserindose no jogo as relações entre a autoestima e a estima dos outros. No fundo, "a vergonha é um sentimento psicológico que possui efeitos de controle social", pois contribui para manter o sujeito ligado às normas sociais. Com essas conclusões, o autor postula que o sentimento de vergonha expressa muito bem a necessidade de pertencer a uma comunidade. Coloca à vista o profundo desejo de pertencimento ao mundo humano (vida, não incesto, não matar, não estuprar, não fazer o mal até fisicamente). Contudo, a que custo se sobressaem tais expressões?

\section{Referências bibliográficas}

ARENDT, H. Eichmann em Jerusalém: um relato sobre a banalidade do mal. São Paulo: Companhia das Letras, 1999.

BAUMAN, Z. Identidade: entrevista a Benedetto Vecchi. Rio de Janeiro: Zahar, 2005.

FREIRE, P. Pedagogia do oprimido. 50ªed. São Paulo: Paz e Terra, 2011.

FREYRE, G. Casa grande e senzala. 52ªed. São Paulo: Global, 2006.

GALLAND, O. Sociologie de la jeunesse. Paris: Armand Colin, 2007.

GOMES, Candido. A educação em novas perspectivas sociológicas. 4aㅡ ed. Rio de Janeiro: Gen, 2011. 